\title{
A GENOTYPE-ENVIRONMENT EXPERIMENT ON STRAWBERRIES IN SCOTLAND
}

\author{
H. J. GOODING, D. L. JENNINGS* and P. B. TOPHAM* \\ Scottish Horticultural Research Institute, West of Scotland Unit, \\ Auchincruive, Ayr KA6 5AE.
}

Received 20.v.74

\section{SUMMARY}

Seedlings from a partial $8 \times 8$ diallel were propagated and grown at Auchincruive in the west of Scotland and at Invergowrie in the east in order to identify parents which transmit stability for yield and its components and to identify genotypes prone to barrenness.

Growth was slower initially at Invergowrie, but once established the plants achieved larger size. Gorella, Cambridge Favourite and 53Q13 transmitted most vigour whilst 60CE5 gave largest numbers of crowns.

Site had a major effect on inflorescences per crown, there being 30 per cent less at Invergowrie than Auchincruive. Parents most closely related to wild species (53Q 13, 60CE5 and Cambridge Favourite) were the most prepotent for high inflorescences per crown. Crosses involving Cambridge Favourite and 53Q13 were the most stable whilst those involving Redgauntlet and Talisman were least stable.

Low inflorescences per crown at Invergowrie was partially compensated for by greater numbers of fruits per inflorescence. Site had a minor effect on fruit size. Gorella, Redgauntlet and Talisman progenies gave the largest fruit and 53 Q 13 the smallest.

Close association between stability and inflorescence production simplified selection for stability and, because the effects of site and general combining ability were so much more important than their interactions, selection at either site for adequate inflorescence numbers should ensure stability.

Selection should not be unduly influenced by total yield since in unstable types similar yields may be achieved through different pathways. Those which depend on high fruit numbers per inflorescence were unreliable and because of the differences between genotypes it is important to measure the yield components of individual selections.

\section{INTRODUGTION}

GeNotypes selected at Auchincruive in the west of Scotland frequently produce fewer inflorescences and are vegetatively more vigorous when grown at Invergowrie in the east of Scotland. This growth difference has often resulted, at Invergowrie, in low yields and even barrenness in individual plants of Crusader, Templar and Marmion, all of which yield more consistently at Auchincruive and in the south of England. Cambridge Favourite is not sensitive to this site effect. Williams (1974) also showed that Redgauntlet, Cambridge Favourite and Gorella yield unequally in different environments in England and others have observed variation in inflorescence production within very small areas. Guttridge and Anderson (1974), for example, recorded that Crusader produced few barren crowns when grown in one field at the S.H.R.I. Invergowrie, and a high proportion in another,

* Address: S.H.R.I., Invergowrie, Dundee DD2 5DA. 
while barrenness has also been observed at a site only four miles from Auchincruive. The cause of these differences in behaviour is unknown, though it is reported that inflorescence initiation may be affected by date of rooting of runners (Webb and White, 1971) and that crown number is increased by shelter (Waister, 1972). The problem is frequently overcome by defoliating after fruiting (Mason, 1966), but in practice this operation is not always done effectively or at the correct time, and it is desirable to have genotypes which are not dependent upon it. Genotype-environment interactions are therefore of fundamental importance in determining a breeding policy whose aim is to select genotypes adapted to a wide range of conditions. A study was therefore made of vegetative and reproductive development on a range of genotypes at Auchincruive and Invergowrie in order to identify the parents which transmit the greatest stability and highest yields to their progenies and also to seek a method of recognising genotypes prone to barrenness.

\section{Materials AND methods}

Twenty of the possible 28 crosses of a diallel between eight parents were grown (fig. 2). Twenty-five genotypes from each family were propagated to provide one plant for Auchincruive and one for Invergowrie.

The Auchincruive site was the one described by Gooding (1972) and is infected with red core disease (Phytophthora fragariae). The Invergowrie site was known as Laboratory Field and described by Guttridge and Anderson (1974); it was uninfected by red core disease but has a reputation for producing barren strawberry plants.

Planting dates extended from May to August 1969 but were coincided as far as possible for each site. The surviving plants were recorded for plant size, crown number, inflorescences per crown and fruit number per inflorescence in 1970 and 1971 and for fruit size in 1971 .

The parents were selected to represent a wide range of germplasm and behaviour and were:

1. Cambridge Favourite. The most commonly grown cultivar in the U.K. with a reputation as a reliable cropper with some field resistance to red core disease. It is several generations removed from one of Etter's Fragaria chiloensis clones (Darrow, 1966).

2. Glasa. An early-forcing cultivar, highly susceptible to red core disease.

3. Gorella. Widely grown in Europe, large fruited and susceptible to red core disease.

4. Redgauntlet. The second most important cultivar in Britain. It lacks field resistance to red core and is subject to barrenness at Invergowrie.

5. Talisman. A sister seedling of Redgauntlet which is slightly more resistant to red core disease but also occasionally subject to barrenness.

6. 53Q13. A first generation derivative of $F$. virginiana clone I with wild-type characteristics such as small, soft fruit. It is highly field resistant to red core.

7. 59BN17. A high yielding large-fruited selection.

8. 60CE5. A derivative of Siletz and Talisman with high field resistance to red core but poor fruit quality. Like Cambridge Favourite, it is a few generations removed from one of Etter's $F$. chiloensis clones. 


\section{Statistical analyses}

General combining ability (G.C.A.) values were calculated for each parent using the method of Gilbert (1967) for fitting parental constants, referred to as parental values. Analyses were restricted to those seedlings which survived at both sites until the end of 1971. This reduced the total number of genotypes to 434 but at least 20 survived in each family.

The complete data were analysed to determine the relative sizes of G.C.A. effects, interaction or specific combining ability (S.C.A.) effects, main effect of years and sites, and their various interactions; but, for further analysis of the genotype-environment interactions using the method of Perkins and Jinks (1968), the family size was standardised to 19 by randomly eliminating genotypes in excess of this number. In this analysis regressions of family means from sites and years are compared with environment means derived from the whole population. Results of these analyses are presented only for inflorescences per crown and fruits per inflorescence where significant heterogeneity of regressions were obtained.

\section{Results \\ (i) Plant size}

The family means, which were obtained from measurements (in centimetres) made in early June, were calculated from log height plus log width 1 plus $\log$ width 2, i.e. width measured in two directions at right angles. The majority of families established more slowly at Invergowrie where growth was at first less than at Auchincruive, but once established the Invergowrie plants attained significantly larger size (table 1 ).

TABLE 1

Population means for components of yield

\[ \begin{array}{c}\text { Character } \\ (\text { logs })\end{array} \]
Plant size
Crown number (CN)
Inflorescence/crown (I/C)
Fruit number/inflorescence (F/I)
Fruit size (FS)
Estimated total yield
$(\mathrm{CN}+\mathrm{I} / \mathrm{C}+\mathrm{F} / \mathrm{I}+\mathrm{FS})$

G.C.A. estimates (table 2) indicate that Glasa was one of the most prepotent parents for vigour at Invergowrie but not at Auchincruive, where its progenies suffered severely from red core disease. Gorella and Cambridge Favourite transmitted the most vigour over all environments but the progenies of 53 Q 13 were especially vigorous at Auchincruive, probably because of their high field resistance. By contrast, Talisman and Redgauntlet transmitted poor growth in all tests possibly due to inbreeding depression particularly in family 10 (the sibcross which was planted latest) and to a lesser extent in families 7 and 20. 
The analysis of variance (table 3 ) shows that years had the largest effect but that the two sites gave different results in the two years. G.C.A. effects were also important as were their interactions with sites. The significant S.C.A. variance indicates that particular parental combinations responded differently.

TABLE 2

General combining ability (G.C.A.) estimates for log plant size

$\begin{array}{lccccc} & \text { A } 1970 & \text { A } 1971 & \text { I } 1970 & \text { I } 1971 & \text { Combined } \\ \text { 1. C. Favourite } & 5 \cdot 73 & 5 \cdot 64 & 5 \cdot 24 & 5 \cdot 68 & 5 \cdot 57 \\ \text { 2. Glasa } & 5 \cdot 34 & 5 \cdot 37 & 5 \cdot 57 & 5 \cdot 78 & 5 \cdot 52 \\ \text { 3. Gorella } & 5 \cdot 55 & 5 \cdot 41 & 5 \cdot 60 & 5 \cdot 88 & 5 \cdot 61 \\ \text { 4. Redgauntlet } & 5 \cdot 02 & 5 \cdot 08 & 5 \cdot 20 & 5 \cdot 67 & 5 \cdot 25 \\ \text { 5. Talisman } & 4 \cdot 71 & 5 \cdot 10 & 4 \cdot 91 & 5 \cdot 43 & 5 \cdot 04 \\ \text { 6. 53Q13 } & 5 \cdot 59 & 5 \cdot 85 & 5 \cdot 20 & 5 \cdot 57 & 5 \cdot 55 \\ \text { 7. 59BN17 } & 5 \cdot 40 & 5 \cdot 60 & 5 \cdot 09 & 5 \cdot 74 & 5 \cdot 46 \\ \text { 8. 60CE5 } & 5 \cdot 21 & 5 \cdot 50 & 4 \cdot 92 & 5 \cdot 49 & 5 \cdot 28\end{array}$

$\mathrm{A}=$ Auchincruive; $\mathbf{I}=$ Invergowrie.

\section{(ii) Crown number}

The data for main crowns was recorded during August and September. The pattern was similar to that for plant size with numbers increasing with plant age but with the largest increase at Invergowrie (table 1). High G.G.A. values were obtained for 60GE5 and low ones for Redgauntlet and Talisman (table 4), some of whose progenies were subject to inbreeding depression which is more evident in the presence of red core (Gooding, 1973).

TABLE 3

Analyses of variance for $\log$ plant size, log crown number, log inflorescence/crown and $\log$ fruit number/inflorescence

Years

Sites

Years/sites

General combining ability (G.C.A.)

G.C.A. $\times$ years

G.C.A. $\times$ sites

G.C.A. $\times$ years $\times$ sites

Specific combining

$$
\text { ability (S.C.A.) }
$$

S.C.A. $\times$ years

S.C.A. $\times$ sites

S.C.A. $\times$ years $\times$ sites

d.f. for residual (within family)

d.f.

V.R.

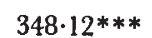

$4 \cdot 23 *$

$135 \cdot 35 * * *$

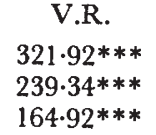

V.R.

V.R.

1

$41 \cdot 96 * * *$

$5 \cdot 07 * * *$
$15 \cdot 98 * * *$

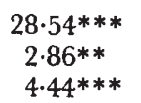

$0.85 \mathrm{nss}$.

$1 \cdot 73$ n.s.
$16 \cdot 34 * * *$
1.08 n.s.
$3 \cdot 22$ **

0.84 n.s.

1.49 n.s. 4.05***

1.97 n.s.

$\begin{array}{lr}12 & 12 \cdot 53 * * * \\ 12 & 1.30 \text { n.s. } \\ 12 & 4.88 * * * \\ 12 & 1.47 \text { n.s. }\end{array}$

$10 \cdot 61 * * *$
$0 \cdot 80$ n.s.
$2 \cdot 74 * *$

$2 \cdot 36 * *$

$7 \cdot 08 * * *$

0.56 n.s.

0.82 n.s.

$1 \cdot 35$ n.s.

0.87 n.s.

1.60 n.s.

0.067 n.s. $\quad 0.73$ n.s.

1716

1468

Table 3 shows that years and sites were almost equally important and that interaction between them was also highly significant. Both G.C.A. and S.G.A. effects were highly significant but the former was most important. 


\section{(iii) Inflorescences per crown}

The effect of years on inflorescences per crown was minor compared to the effect of sites (table 1), the actual overall mean inflorescences per crown being 0.9 at Auchincruive and only 0.6 at Invergowrie. Hence table 3 shows no significant difference between years but a highly significant one

TABLE 4

General combining ability (G.C.A.) estimates for log crown number

1. C. Favourite

2. Glasa

3. Gorella

4. Redgauntlet

5. Talisman

6. $53 \mathrm{Q} 13$

7. $59 \mathrm{BN} 17$

8. $60 \mathrm{CE} 5$

$\begin{array}{ccccc}\text { A } 1970 & \text { A } 1971 & \text { I } 1970 & \text { I } 1971 & \text { Combined } \\ 1.31 & 1.35 & 1.12 & 1.42 & 1.30 \\ 1.30 & 1.38 & 1.33 & 1.41 & 1.35 \\ 1.20 & 1.28 & 1.20 & 1.36 & 1.26 \\ 0.79 & 0.94 & 0.95 & 1.22 & 0.97 \\ 0.78 & 1.07 & 1.00 & 1.45 & 1.07 \\ 1.14 & 1.40 & 1.24 & 1.39 & 1.29 \\ 1.05 & 1.31 & 1.17 & 1.53 & 1.27 \\ 1.37 & 1.57 & 1.30 & 1.65 & 1.47\end{array}$

$\mathrm{A}=$ Auchincruive; $\mathbf{I}=$ Invergowrie.

between sites. G.C.A. effects (table 5) were highly significant with 53Q13, $60 \mathrm{CE} 5$ and Cambridge Favourite having the highest parental values. These three parents are the most closely related to wild species, $53 Q 13$ to $F$. virginiana and the others to $F$. chiloensis, though more distantly.

TABLE 5

General combining ability (G.C.A.) estimates for log inflorescence/crown

\begin{tabular}{lrrrrr} 
& A 1970 & A 1971 & I 1970 & I 1971 & Combined \\
1. C. Favourite & 0.05 & 0.07 & -0.25 & -0.19 & -0.08 \\
2. Glasa & -0.15 & -0.13 & -0.17 & -0.35 & -0.20 \\
3. Gorella & -0.13 & -0.16 & -0.35 & -0.61 & -0.31 \\
4. Redgauntlet & -0.19 & -0.14 & -0.67 & -0.75 & -0.44 \\
5. Talisman & -0.20 & -0.14 & -0.59 & -0.87 & -0.45 \\
6. 53Q13 & 0.12 & 0.16 & -0.14 & 0.03 & 0.04 \\
7. 59BN17 & -0.22 & -0.10 & -0.42 & -0.56 & -0.32 \\
8. 60CE5 & -0.05 & 0.07 & -0.19 & -0.03 & -0.05 \\
\multicolumn{5}{c}{ A $=$ Auchincruive; I = Invergowrie. }
\end{tabular}

The large variance ratio (V.R.) for G.C.A. effects and the relatively small interactions with years and sites indicates that the best parents could probably have been identified at either site, while the significant S.C.A. and its non-significant interactions indicate that outstanding families could also have been identified irrespective of site or season. However, further study of the interactions revealed significant variation between families in their linear response to environment. In this analysis regressions of family means against environment means are compared and some examples are given in fig. 1. For instance, families 16 and 12 are much less sensitive to environmental change than family 19, which is derived from a cross between the present most important cultivars in Britain. The performance of a family can therefore be designated by a " response factor", the " $b$ " value of the regression line, as well as by its mean performance. All the regression values 
from this analysis were plotted against the family means (fig. 2) to give a summary of the families' stability (Findlay and Wilkinson, 1963). A significant correlation $(r=-0.4 ; \mathrm{P}=0.01)$ was obtained with these values

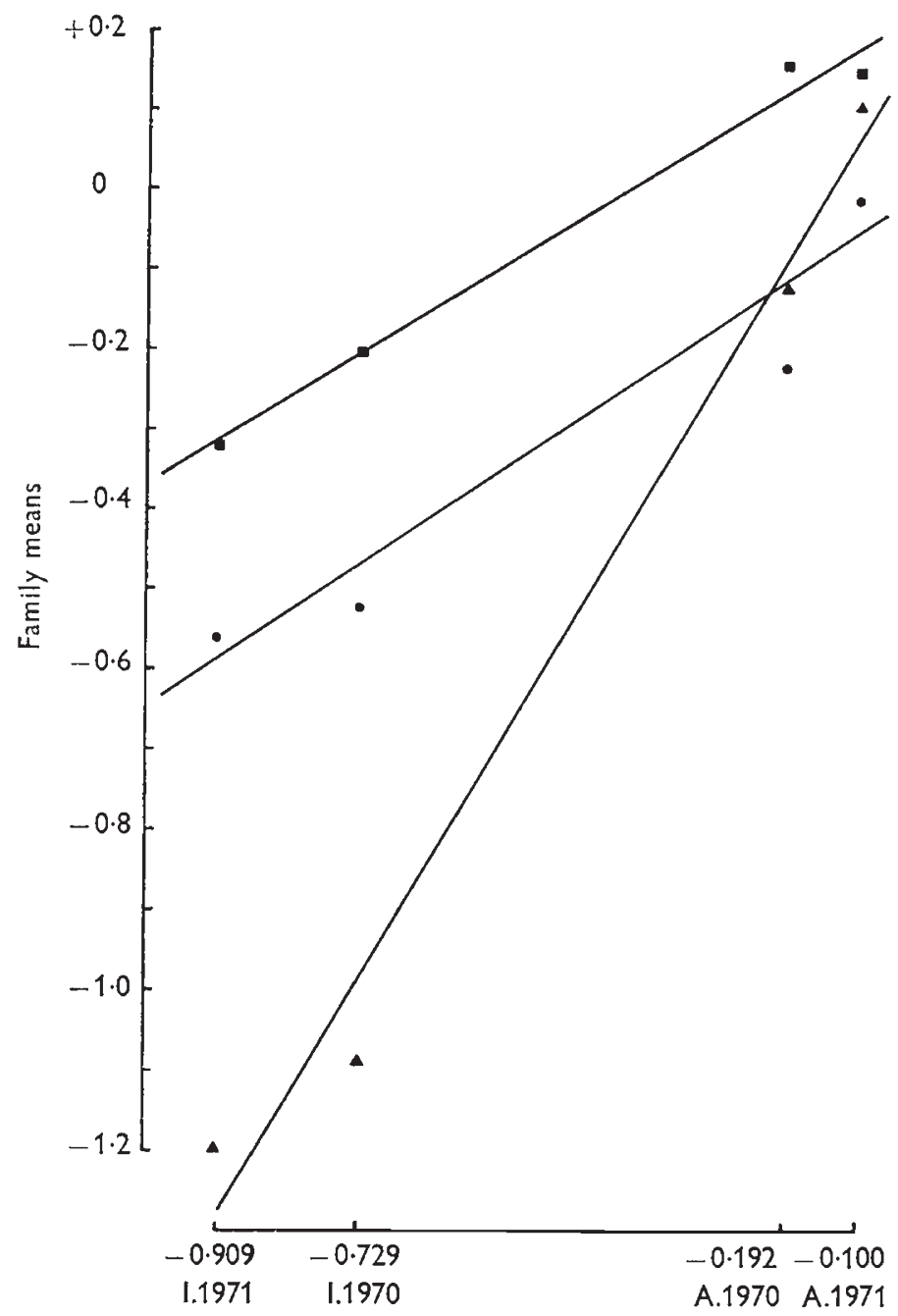

Fig. 1.-Regressions of $\log$ inflorescences per crown against environment means for three families: family 12, Gorella $\times 60$ CE5 (circles), where $b-1=-0.3897$; family 16 , 60 CE5 $\times$ Cambridge Favourite (squares), where $b-1=-0.3854$; and family 19, Redgauntlet $\times$ Cambridge Favourite (triangles), where $b-1=0.6618$.

indicating that high inflorescences per crown are associated with low regression values, i.e. the families with high means tended to be the most stable. For example, families 2, 9, 11 and 16 which mainly feature Cambridge Favourite and 53Q13 crosses had high means and " $b$ " values near or below 1 indicating that they were more adapted to all environments. Conversely, families $1,10,17$ and 19 which feature Redgauntlet and Talisman were suited only to favourable environments. 


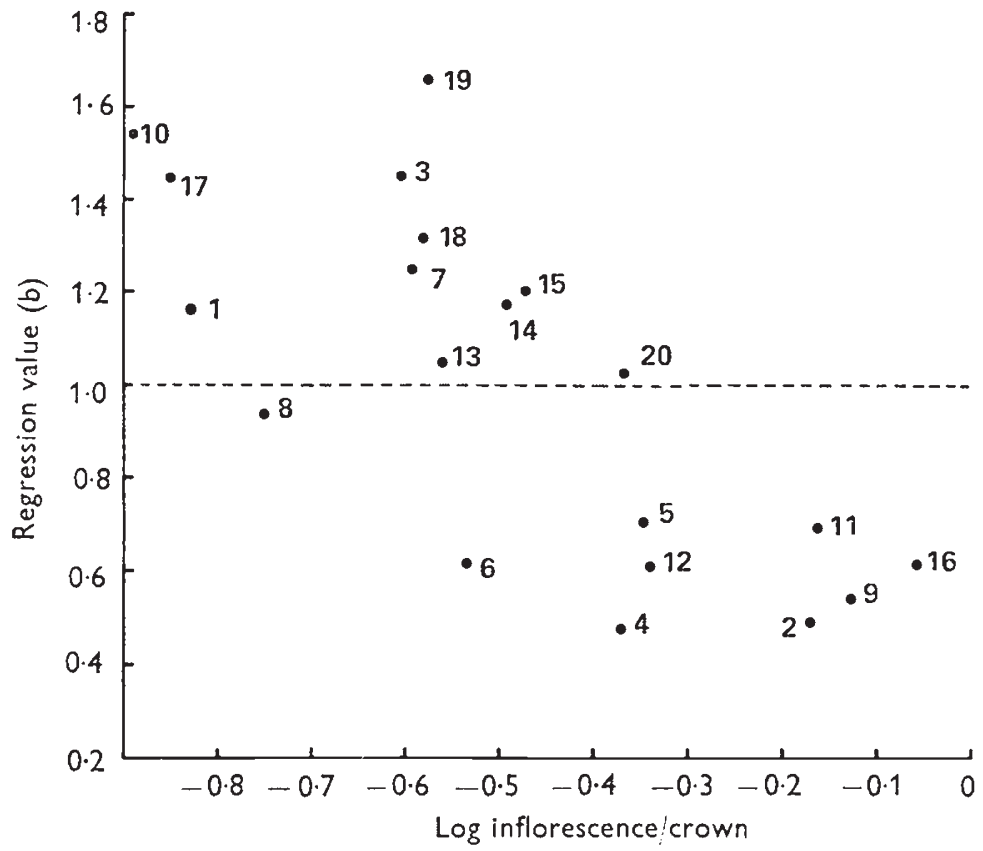

Frg. 2.-Comparative stability of families for $\log$ inflorescence per crown.

Key to families and their parents

$\begin{array}{cccc}\text { Family No. } & \text { Cross } & \text { Family No. } & \text { Cross } \\ 1 & 4 \times 2 & 11 & 2 \times 1 \\ 2 & 6 \times 1 & 12 & 3 \times 8 \\ 3 & 7 \times 5 & 13 & 3 \times 1 \\ 4 & 7 \times 8 & 14 & 5 \times 1 \\ 5 & 7 \times 1 & 15 & 7 \times 6 \\ 6 & 7 \times 2 & 16 & 8 \times 1 \\ 7 & 5 \times 8 & 17 & 5 \times 3 \\ 8 & 7 \times 4 & 18 & 7 \times 3 \\ 9 & 3 \times 6 & 19 & 4 \times 1 \\ 10 & 5 \times 4 & 20 & 4 \times 8\end{array}$

Parents: 1 =Cambridge Favourite; $2=$ Glasa; $3=$ Gorella; $4=$ Redgauntlet; $5=$ Talisman $; 6=53 \mathrm{Q} 13 ; 7=59 \mathrm{BN} 17 ; 8=60 \mathrm{CE} 5$.

(iv) Fruit number per inflorescence

Counts of mature fruit were made either on inflorescences selected at random or on all the inflorescences if few were present. The results (tables 1 and 3) indicate a large site effect. The plants at Invergowrie apparently tended to compensate for their low inflorescences per crown by an increase in fruits per inflorescence, though fruit numbers were reduced with increasing plant age and size.

G.C.A. and S.C.A. effects were again important but neither of them interacted with years; the only significant interaction was between G.C.A. and sites, Gorella and Redgauntlet both giving lower values at Auchincruive (table 6). The parent with the highest value was 59BN1 7 and the one with 
the lowest was 60CE5, whose progenies had such large numbers of inflorescences that the average number of fruit present was possibly restricted physiologically.

TABLE 6

General combining ability (G.C.A.) estimates for log fruit number/inflorescence

$\begin{array}{lccccc} & \text { A } 1970 & \text { A } 1971 & \text { I } 1970 & \text { I } 1971 & \text { Combined } \\ \text { 1. C. Favourite } & 0.97 & 0.82 & 0.95 & 0.92 & 0.91 \\ \text { 2. Glasa } & 0.82 & 0.87 & 1.12 & 0.85 & 0.91 \\ \text { 3. Gorella } & 0.92 & 0.91 & 1.26 & 1.15 & 1.06 \\ \text { 4. Redgauntlet } & 0.88 & 0.85 & 1.21 & 1.10 & 1.01 \\ \text { 5. Talisman } & 0.91 & 0.99 & 1.13 & 1.00 & 1.01 \\ \text { 6. 53Q13 } & 0.79 & 1.06 & 1.07 & 0.94 & 0.97 \\ \text { 7. 59BN17 } & 1.15 & 1.00 & 1.32 & 1.17 & 1.16 \\ \text { 8. 60CE5 } & 0.70 & 0.70 & 0.76 & 0.60 & 0.62\end{array}$

$\mathrm{A}=$ Auchincruive; $\mathbf{I}=$ Invergowrie.

A regression analysis (table 7) shows that there was a significant heterogeneity of regression indicating that some regression values $(b-1)$ were

TABLE 7

Regression analysis

\begin{tabular}{|c|c|c|c|c|}
\hline & \multicolumn{3}{|c|}{ Log inflorescence/crown } & \multirow{2}{*}{$\begin{array}{c}\text { Log fruit no./inflorescence } \\
\text { V.R. }\end{array}$} \\
\hline & d.f. & V.R. & d.f. & \\
\hline Environments & 3 & $98 \cdot 025 * * *$ & 3 & $90 \cdot 07 * * *$ \\
\hline Genotypes & 19 & $7 \cdot 445 * * *$ & 19 & $20 \cdot 95 * * *$ \\
\hline Heterogeneity of regression & 19 & $2 \cdot 194 * * *$ & 19 & $3 \cdot 22 * * *$ \\
\hline Remainder & 38 & $0 \cdot 727$ n.s. & 38 & $1 \cdot 52^{*}$ \\
\hline Residual & 1433 & & 1221 & \\
\hline
\end{tabular}

positive and others negative. However, because of the low V.R. obtained by $\frac{\text { Heterogeneity of regression }}{\text { Remainder }}(2 \cdot 11)$, most of the $\mathrm{G} / \mathrm{E}$ interactions can be predicted from the linear regressions of the families on the environmental values.

The most stable families were all derived from 59BN17 and, although their "b" values were not significant, they all had high means. The only other families with " $\mathrm{b}$ " values less than 1 , but which approached significance, i.e. were well adapted to all test environments, were 14 and 16, however only the former (Talisman $\times$ Cambridge Favourite) had a high mean.

\section{(v) Fruit size}

Ripe fruits were allocated to five size grades, using clay models to ensure uniformity of recording between the two sites. The results (tables 1 and 9) show that there was a negligible overall site effect and that most of the variation can be attributed to G.C.A. and its interaction with sites. S.C.A. effects bordered on significance. The low G.C.A. value (table 8) for 53Q13 was expected because of its close relationship to a species hybrid and its 
wild-type small fruit. The highest parental value was obtained by Gorella, which is noted for its large fruit.

\section{TABLE 8}

General combining ability (G.C.A.) estimates for log fruit size

$\begin{array}{lccc} & \text { A } 1971 & \text { I } 1971 & \text { Combined } \\ \text { 1. C. Favourite } & 0.40 & 0.41 & 0.40 \\ \text { 2. Glasa } & 0.34 & 0.41 & 0.38 \\ \text { 3. Gorella } & 0.43 & 0.49 & 0.46 \\ \text { 4. Redgauntlet } & 0.35 & 0.44 & 0.40 \\ \text { 5. Talisman } & 0.43 & 0.42 & 0.42 \\ \text { 6. 53Q13 } & 0.08 & 0.03 & 0.06 \\ \text { 7. 59BN17 } & 0.41 & 0.49 & 0.45 \\ \text { 8. 60CE5 } & 0.37 & 0.09 & 0.23\end{array}$

$\mathrm{A}=$ Auchincruive; $\mathbf{I}=$ Invergowrie.

\section{(vi) Estimated yield}

Estimates of total yield in 1971 were obtained from log crown number + $\log I / C+\log F / I+\log$ fruit size. The values obtained (table 1 ) were similar for the two sites which indicates that families tended to achieve their yield

TABLE 9

Analyses of variance for $\log$ fruit size and estimated total yield

\begin{tabular}{|c|c|c|c|}
\hline & d.f. & $\begin{array}{c}\text { Log fruit size } \\
\text { V.R. }\end{array}$ & $\begin{array}{c}\text { Estimated total yield } \\
\text { V.R. }\end{array}$ \\
\hline Sites & 1 & 0.01 n.s. & $5 \cdot 21^{*}$ \\
\hline General combining ability (G.C.A.) & 7 & $14 \cdot 74 * * *$ & $3.52 * *$ \\
\hline G.C.A. $\times$ sites & 7 & $3 \cdot 93 * *$ & 1.58 n.s. \\
\hline Specific combining ability (S.C.A.) & 12 & 1.73 n.s. & $3 \cdot 57 * *$ \\
\hline S.C.A. $\times$ sites & 12 & $1.87^{*}$ & $1 \cdot 17$ n.s. \\
\hline Residual & 724 & & \\
\hline
\end{tabular}

through different pathways at Auchincruive and Invergowrie. The larger number of inflorescences per crown at Auchincruive tended to be compensated for by higher crown numbers and larger numbers of fruit per inflorescence at Invergowrie.

TABLE 10

General combining ability (G.C.A.) estimates for estimated total yield

$\begin{array}{lccc} & \text { A } 1971 & \text { I } 1971 & \text { Combined } \\ \text { 1. C. Favourite } & 2 \cdot 63 & 2 \cdot 33 & 2 \cdot 48 \\ \text { 2. Glasa } & 2 \cdot 46 & 2 \cdot 49 & 2 \cdot 48 \\ \text { 3. Gorella } & 2 \cdot 50 & 2 \cdot 43 & 2 \cdot 46 \\ \text { 4. Redgauntlet } & 2 \cdot 09 & 2 \cdot 12 & 2 \cdot 11 \\ \text { 5. Talisman } & 2 \cdot 46 & 2 \cdot 50 & 2 \cdot 48 \\ \text { 6. 53Q13 } & 2 \cdot 69 & 2 \cdot 36 & 2 \cdot 52 \\ \text { 7. 59BN17 } & 2 \cdot 59 & 2 \cdot 83 & 2 \cdot 71 \\ \text { 8. 60CE5 } & 2 \cdot 70 & 2 \cdot 31 & 2 \cdot 50\end{array}$

$\mathrm{A}=$ Auchincruive; $\mathbf{I}=$ Invergowrie.

Table 10 of G.C.A. values shows that $59 \mathrm{BN} 17$ transmitted high yield. It combined well with Talisman and 60CE5, possibly because these parents 
complemented each other for their yield components. Both G.G.A. and S.C.A. were significant but their interaction with site was not significant indicating that selection for yield should be effective at either site (table 9).

\section{Discussion and conclusion}

The capacity of a genotype to give a stable performance is not always desirable because a stable plant may not advantageously be responsive to a favourable environment. But stable performance in the environments studied here is a vital requirement of a genotype selected for use throughout the United Kingdom. Even when higher yield per inflorescence tended to compensate for reduction in inflorescence number, there was no guarantee of stable yield because such compensation was not possible in genotypes where inflorescence formation was precluded altogether. Although Guttridge and Anderson (1974) note that the cause of barrenness is not understood, they considered that it is more likely to occur in large than in small plants. Hence measures to increase growth and plant size may not increase yields in certain environments and may even decrease them. In these environments there is clearly a danger that attempts to increase yield either by breeding or by cultural means will tend to fall short of theoretical possibilities if they also induce an increase in plant size, because of this tendency for fewer inflorescences to be formed in large plants. This occurred when certain cultivars were freed of virus by heat therapy and subsequently grew more vigorously but gave lower yields (Rogers and Fronow, 1958). By contrast, increasing the vigour of a stable cultivar like Cambridge Favourite by freeing it of virus increased yield as also did shelter (Waister, 1972). Our results show how this danger can be avoided by selection of genotypes showing stability for inflorescence formation.

The parents showing most stability for inflorescence numbers per crown were Cambridge Favourite, 53Q13 and 60CE5. Further use of these parents and others which transmit a similar stability for inflorescence production is desirable, but though this policy is compatible with breeding for field resistance to red core disease (Gooding, 1973) the successful use of 53Q13 has hitherto been overshadowed by its tendency to transmit small fruit.

Variation in the stability of selections reflects not only on their genetical relationships to the wild species as such, but also possibly on the different ecotypes originally involved. The frequency of the "barrenness" response suggests that selection during domestication sometimes occurred in climates where low inflorescences per crown was not a factor limiting yield, and that more adapted genotypes should be located for breeding heavy cropping cultivars suited to certain U.K. environments.

The close connection found between stability and inflorescence production simplifies the procedure that will be necessary to select for stability. Moreover, the main effects of sites and G.C.A. were so much more important than their interaction effect that selection for genotypes which produce adequate inflorescence numbers at both sites should be possible at either site. Selection must be for high inflorescence numbers and not unduly influenced by total yield, since in the unstable types similar yields may be achieved through different pathways which are determined by the environment, and pathways which depend on high fruit numbers per inflorescence are unreliable. The results imply a high dependence of one yield component upon 
the level of the component which precedes it in development, giving a complex interdependence between yield components. For inheritance studies they should therefore be considered in combination and the techniques of Thomas et al. (1971) may be suitable. Easton and Clements (1973) emphasise the importance of examining individual genotypes and this applies especially to vegetatively propagated crops. Marmion and Montrose illustrate their point. They are both from the cross Crusader $\times$ Redgauntlet and both parents exhibit barrenness on certain sites, and yet Montrose in contrast to Marmion has high inflorescence numbers and has yielded well in trials on a site prone to barrenness problems.

Acknowledgment.-The authors thank the recording staff for their team spirit.

\section{REFERENCES}

DARROW, GEORGE M. 1966. The Strawberry. Holt, Rinehart and Winston, pp. 447.

EASTON, H. s., AND CLEMENTS, R. J. 1973. The interaction of wheat genotypes with a specific factor of the environment. F. agric. Sci. Camb., 80, 43-52.

FINDLAY, K. W., AND WILKINSON, G. N. 1963. The analysis of adaptation in a plant-breeding programme. Aust. F. Biol. Sci., 14, 742-754.

GILBERT, N. 1967. Additive combining abilities fitted to plant breeding data. Biometrics, $23,45-49$

Gooding, H. J. 1972. Studies on field resistance of strawberry varieties to Phytophthora fragariae. Euphytica, 21, 63-70.

Gooding, H. J. 1973. Methods of evaluating plants as sources of field resistance to Phytophthora fragariae Hickman. Euphytica, 22, 141-149.

GUTTRIDGE, C. G., AND ANDERSON, H. M. 1974. The relationship between plant size and fruitfulness in strawberry in Scotland. Hort. Res., 13, 125-135.

MASON, D. T. 1966. Inflorescence initiation in the strawberry. I. Initiation in the field and its modification by post-harvest defoliation. Hort. Res., 6, 33-44.

PERKINS, JEAN M., AND JINKS, J. L. 1968. Environmental and genotype-environmental components of variability. III. Multiple lines and crosses. Heredity, 23, 339-356.

ROGERS, W. S., AND FRONOW, MURIEL A. 1958. The field performance of heat-treated strawberry clones. Rep. E. Malling Res. Sta. for 1957, 50-56.

THOMAS, R. L., GRAFIUS, J. E., AND HAHN, s. K. 1971. Genetic analysis of correlated sequential characters. Heredity, 26, 177-188.

WAISTER, P. D. 1972. Wind as a limitation on the growth and yield of strawberries. F. hort. Sci., 47, 411-418.

WEBB, R. A., AND WHITE, B. A. 1971. The effect of rooting date on flower production in the strawberry. F. hort. Sci., 46, 413-423.

WILLIAMS, HEDLEY. 1974. Genotype-environment interaction in strawberry varieties. Hort. Res., 14. In press. 